\title{
Evidence for Glomerular Actions of Epidermal Growth Factor in the Rat
}

\author{
Raymond C. Harris, Richard L. Hoover, Harry R. Jacobson and Kamal F. Badr \\ Division of Nephrology, Department of Medicine and Department of Pathology, Veterans Administration Medical Center and \\ Vanderbilt University School of Medicine, Nashville, Tennessee 37232
}

\begin{abstract}
Epidermal growth factor (EGF), an endogenous mitogenic peptide, has recently been shown to be a potent vasoconstrictor of vascular smooth muscle. In view of its potential role in proliferative and inflammatory renal glomerular diseases, we examined the effects of EGF both on cultured rat mesangial cells and on in vivo glomerular hemodynamics. Mesangial cells possess specific, saturable EGF receptors of differing affinities, with $K_{d}$ 's of 0.1 and $1.7 \mathrm{nM}$, respectively. EGF produced a rapid increase in intracellular pH of $0.12 \pm 0.01 \mathrm{pH} U$, which was sodium dependent and amiloride inhibitable. The addition of EGF to mesangial cells cultured on either glass or dimethylpolysiloxane substratum induced reproducible cell contraction.

Intrarenal EGF infusion did not affect systemic blood pressure or hematocrit but reversibly decreased GFR and renal blood flow from $4.19 \pm 0.33$ to $3.33 \pm 0.26$ and from $1.17 \pm 0.09$ to $0.69 \pm 0.07 \mathrm{ml} / \mathrm{min}$, respectively. Glomerular micropuncture confirmed decreases in single nephron plasma flow and in single nephron GFR (from $142 \pm 9$ to $98 \pm 8$ and from $51.6 \pm 11.7$ to 28.5 $\pm 3.5 \mathrm{nl} / \mathrm{min}$, respectively) which were due to significant increases in both pre- and postglomerular arteriolar resistances (from $1.97 \pm 0.31$ to $2.65 \pm 0.36$ and from $1.19 \pm 0.11$ to $2.00 \pm 0.1510^{10} \mathrm{dyn} \cdot \mathrm{s} \cdot \mathrm{cm}^{-5}$ respectively) and to a significant decrease in the ultrafiltration coefficient, $K_{f}$, which fell from $0.100 \pm 0.019$ to $0.031 \pm 0.007 \mathrm{nl} /(\mathrm{s} \cdot \mathrm{mmHg})$.

These studies demonstrate that mesangial cells possess specific receptors for EGF, and exposure of these cells to physiologic concentrations of EGF results in an in vitro functional response characterized by activation of $\mathrm{Na}^{+} / \mathrm{H}^{+}$exchange and by resultant intracellular alkalinization, as well as by cell contraction. EGF administration in vivo significantly reduces the glomerular capillary ultrafiltration coefficient, $K_{f}$, which, in combination with EGF-induced constriction of both preglomerular and postglomerular arterioles, results in acute major reductions in the rates of glomerular filtration and perfusion.
\end{abstract}

\section{Introduction}

Epidermal growth factor (EGF) ${ }^{1}$ is a $6,000 \mathrm{~mol}$ wt peptide first isolated by Cohen from mouse submaxillary gland (1). Be-

Address all correspondence to Dr. R. C. Harris, Division of Nephrology, S3223 Medical Center North, Vanderbilt University, Nashville, TN 37232. 1988.

Received for publication 20 July 1987 and in revised form 18 March

1. Abbreviations used in this paper: AP, systemic arterial pressure; BCECF, 2'7'-bis(2-carboxy-ethyl)-5(and 6) carboxyfluorescein; $C_{A}$, protein concentration in femoral arteriolar blood plasmas; $C_{E}$, protein

The Journal of Clinical Investigation, Inc.

Volume 82, September 1988, 1028-1039 cause of its actions to accelerate eyelid opening and incisor formation in newborn rodents and its well-documented ability to promote mitogenesis in a wide variety of epithelial and mesenchymal cells in culture, EGF has been considered the prototypical "growth factor" (2). In vivo, it has been shown to mediate maturation of palatal and intestinal epithelia and to accelerate wound and gastric ulcer healing and liver regeneration (3-5). These actions of EGF are mediated by interaction of the peptide with specific cell surface receptors (6).

In addition to its well-documented growth promoting activity, EGF possesses a number of other potentially important biologic effects. These include its ability to inhibit gastric acid secretion and to stimulate arachidonate metabolism $(7,8)$. Of relevance to the present studies is the recent demonstration that EGF can serve as a potent constrictive agent for vascular smooth muscle $(9,10)$.

Glomerular mesangial cells are smooth muscle-like cells of mesenchymal origin. They contain actin and myosin (11) and serve as target cells for a number of vasoactive hormones and autacoids (12). Their contractile function is considered to be an important regulatory mechanism in the control of glomerular filtration (13). In view of the described effects of EGF on smooth muscle cell function $(9,10,14)$, its demonstrated presence in renal tissue, and of the potential for its release from platelets and other cellular elements during glomerular injury (15), the present studies were designed to investigate, in vivo and in vitro, the effects of EGF on mesangial cell function. Our studies demonstrate that mesangial cells in culture possess specific receptors for EGF, and that EGF activates $\mathrm{Na}^{+} / \mathrm{H}^{+}$exchange in these cells. Furthermore, addition of EGF induces contraction of cultured mesangial cells. In addition, in vivo glomerular micropuncture studies reveal that EGF, when infused into the renal artery, causes a reversible fall in the GFR due mainly to a profound reduction of the glomerular capillary ultrafiltration coefficient $\left(K_{\mathrm{f}}\right)$, a phenomenon most likely mediated by mesangial cell contraction (16). Of interest, and in keeping with its known capacity to contract vascular smooth muscle $(9,10)$, EGF also led to constriction of pre- and postglomerular arterioles, thus decreasing glomerular perfusion.

\section{Methods}

Rat mesangial cells were isolated and cultured as previously described (17). The following criteria were used to establish the identity of these

concentration in the surface efferent arteriolar blood plasmas; EGF, epidermal growth factor; FF, filtration fraction; $K_{f}$, glomerular capillary ultrafiltration coefficient; $P_{E}$, pressure in surface efferent arterioles; $\mathbf{P}_{\mathbf{G C}}$, pressure in surface glomerular capillaries; $\mathbf{P}_{\mathbf{T}}$, pressure in proximal tubules; $\mathrm{pH}_{\mathrm{i}}$, intracellular $\mathrm{pH} ; \mathbf{Q}_{\mathbf{A}}$, initial glomerular capillary plasma flow; $\mathbf{R}_{A}$, resistance of single afferent arterioles; $\mathbf{R}_{E}$, resistance of single efferent arterioles; RPF, renal plasma flow; SNFF, single nephron FF; SNGFR, single nephron glomerular filtration rate; TGF- $\alpha$, transforming growth factor alpha; TMACl, tetramethylammonium chloride; $\pi_{A}$, colloid osmotic pressure. 
cells: (a) a stellate or spindle morphology noted using phase contrast microscopy, $(b)$ electron microscopic demonstration of bundles of microfilaments and elongated nuclei, $(c)$ characteristic staining of the filaments with antimyosin antibodies and FITC labeled phalloidin, $(d)$ insensitivity to puromycin and lack of staining for Factor VIII antigen. The studies were performed upon cloned mesangial cells from passages 8-12. The mesangial cells were routinely grown in RPMI 1640, supplemented with $20 \% \mathrm{FCS}$, penicillin $(100 \mathrm{U} / \mathrm{ml})$, and streptomycin $(100 \mu \mathrm{g} / \mathrm{ml}) .24 \mathrm{~h}$ before study, cells were transferred to medium containing $0.4 \%$ FCS.

${ }^{125}$ I-EGF binding studies. Studies of ${ }^{125} \mathrm{I}-\mathrm{EGF}$ binding were performed on mesangial cells grown to confluence in 24-well cluster dishes. The cells were washed with PBS and then exposed to the appropriate concentration of ${ }^{125} \mathrm{I}-\mathrm{EGF}$ in PBS. At the completion of the experiment, the experimental medium was removed and the cells were washed five times with ice-cold buffer. The cells were then dissolved with $1.0 \mathrm{~N} \mathrm{NaOH}$ and the bound radioactivity was determined using a gamma counter (1197; Searle Analytic, Des Plaines, IL). Cell count was determined by counting cells from replicate wells, using a Coulter Counter ZBi (Coulter Electronics, Inc., Hialeah, FL). Nonspecific binding was determined by measuring the amount of ${ }^{125} \mathrm{I}$-EGF bound in the presence of 1,000-fold excess of unlabeled EGF.

Intracellular $\mathrm{pH}\left(\mathrm{pH} \mathrm{H}_{i}\right)$ measurements. In quiescent cells, EGF has been demonstrated to increase $\mathrm{pH}_{\mathrm{i}}$ via activation of $\mathrm{Na}^{+} / \mathrm{H}^{+}$exchange (18). Furthermore, angiotensin II, which is known to decrease GFR and constrict mesangial cells, has recently been shown to activate $\mathrm{Na}^{+} / \mathrm{H}^{+}$exchange in smooth muscle cells $(19,20)$. Therefore, the effects of EGF on $\mathrm{pH}_{\mathrm{i}}$ regulation in cultured mesangial cells was studied. Measurement of $\mathrm{pH}_{\mathrm{i}}$ was performed using mesangial cells grown on glass coverslips. Cells were exposed for $1 \mathrm{~h}$ to $5 \mu \mathrm{M} 2^{\prime} 7^{\prime}$-bis(2-carboxyethyl)-5(and-6) carboxyfluorescein (BCECF) in a nominally bicarbonate free medium, consisting of $140 \mathrm{mM} \mathrm{NaCl}, 5 \mathrm{mM} \mathrm{KCl}, 1.5 \mathrm{mM}$ $\mathrm{CaCl}_{2}, 1.0 \mathrm{mM} \mathrm{MgCl}$, $10 \mathrm{mM}$ glucose, $10 \mathrm{mM}$ Hepes, pH 7.40. Fluorescent measurements were performed using a Nikon DIAPHOT TMD inverted microscope with an epifluorescence attachment and a Nikon P1 Photometer (Nikon, Inc., Garden City, NY). Signals were measured from single cells or a small number of contiguous cells. The excitation wavelength was rapidly varied between 450 and $490 \mathrm{nM}$ by the use of narrow-band pass filters (Ditric Optics, Inc., Hudson, MA), and the emitted fluorescence was measured at $530 \mathrm{nM} . \mathrm{pH}_{\mathrm{i}}$ was then determined by comparing the ratio of the emitted fluorescence at 490 and $450 \mathrm{~nm}$ excitations, as extracellular $\mathrm{pH}$ was varied. At the end of each experiment, cytoplasmic $\mathrm{pH}$ was calibrated by the method of Thomas et al., in which the cells were exposed to solutions of different $\mathrm{pH}$, which contained $130 \mathrm{mM} \mathrm{KCl}$, in the presence of the $\mathrm{K}^{+} / \mathrm{H}^{+}$ ionophore, nigericin $(10 \mu \mathrm{M})(21)$.

Contractility studies. Early passage (1-3) rat mesangial cells were seeded either directly on glass coverslips or upon glass coverslips coated with dimethylpolysiloxane $(60,000$ centistokes), using the method of Harris et al. (22) and Singhal et al. (23). Experiments were conducted $24 \mathrm{~h}$ after seeding and were performed using a camera equipped inverted Nikon microscope. The temperature of the bath was maintained at $37^{\circ} \mathrm{C}$. by means of a microscope-associated environmental chamber (Nikon).

Micropuncture studies. All experiments were performed on anesthetized adult male Munich-Wistar rats weighing 234-270 g that were prepared for micropuncture according to protocols described previously (24). In brief, after Inactin anesthesia $(100 \mathrm{mg} / \mathrm{kg}$, i.p.), the left femoral artery was catheterized with PE 50 tubing, which was used to monitor mean systemic arterial pressure (AP) by means of a pressure transducer (P23Db, Statham Instruments) that was connected to a direct writing recorder (Gould Inc., Oxnard, CA). This catheter was also used for sampling blood.

After a tracheostomy, polyethylene catheters were inserted into both jugular veins for infusion of plasma and $\left[{ }^{3} \mathrm{H}\right]$ inulin $(2.4 \mu \mathrm{Ci} / \mathrm{min})$ at $1.2 \mathrm{ml} / \mathrm{h}$. The left kidney was exposed by a left subcostal incision, separated from the surrounding fat, and suspended on a Lucite holder. The kidney surface was illuminated with a fiberoptic light source and bathed with isotonic $\mathrm{NaCl}$. A 30-gauge needle was placed in the abdominal aorta at the take off of the left renal artery. Through this needle a maintenance infusion of $0.9 \% \mathrm{NaCl}$ at the rate of 0.025 $\mathrm{ml} / \mathrm{min}$ was initiated. Also, an electromagnetic flow probe was placed around the left renal artery and connected to a flow meter (Carolina Medical Electronics Inc., King, NC) to allow for continuous monitoring of renal blood flow rate. Homologous rat plasma was administered intravenously at a rate of $10 \cdot \mathrm{ml} / \mathrm{kg}$ per $\mathrm{h}$ for $45 \mathrm{~min}$, which was followed by a reduction in infusion rate to $1.5 \mathrm{ml} / \mathrm{kg}$ per $\mathrm{h}$ for the remainder of the experiment. This protocol of plasma administration has been shown previously to replace adequately surgically-induced plasma losses, thus maintaining euvolemia (24).

In all experiments, micropuncture measurements were performed 45-60 min after the end of surgical preparation and were carried out as follows: exactly timed (1-2 min) samples of fluid were collected from surface proximal convolutions of each of three to four nephrons for determination of flow rate and inulin concentration. Tubule fluid-toplasma inulin concentration ratio and single nephron glomerular filtration rate (SNGFR) were then calculated. Coincident with these tubule fluid collections, two or three samples of femoral arterial blood were obtained in each period for determination of systemic arterial hematocrit and plasma concentration of total protein and inulin. Also, at least three samples of blood were obtained from surface efferent arterioles (star vessels) for determination of efferent arteriolar protein concentration. In addition, two or three samples of urine from the experimental kidney were collected for the determination of flow rate, protein concentration, inulin concentration, and for the calculation of whole kidney GFR. For these urine collections, indwelling polyethylene ureteral catheters (PE 10) were used.

Time-averaged hydraulic pressures were measured in surface glomerular capillaries $\left(P_{G C}\right)$, proximal tubules $\left(P_{T}\right)$, and surface efferent arterioles $\left(\mathrm{P}_{\mathrm{E}}\right)$ using a continuous recording, servo-null micropipette transducer system (model 5; Instrumentation for Physiology and Medicine, San Diego, CA). Micropipettes with outer tip diameters of 2-4 $\mu \mathrm{m}$ that contained $2.0 \mathrm{M} \mathrm{NaCl}$ were used. Hydraulic output from the servo-nulling system was coupled electronically to a second channel of the Gould recorder by means of a pressure transducer. Experiments were performed on two groups of rats.

Group I $(n=5)$. In this group, whole kidney and micropuncture measurements were performed during an initial baseline period and then repeated during a second period in which the EGF vehicle infusion $(0.9 \% \mathrm{NaCl})$ in the left renal artery was maintained. These animals served as time controls.

Group II $(n=9)$. In this group, the same measurements were performed during an initial baseline period and were then repeated during intrarenal arterial administration of purified mouse EGF in a dose of $500 \mathrm{ng} / \mathrm{kg}$ per $\min$ for $\sim 30 \mathrm{~min}$ at a rate equal to 0.025 $\mathrm{ml} / \mathrm{min}$. This dose was designed to achieve an intrarenal vascular concentration of EGF equal to $\sim 3 \mathrm{nM}$, a value close to our calculated $K_{d}$ obtained in the in vitro binding studies described above (see $\mathrm{Re}$ sults).

Analytical. Colloid osmotic pressure of plasma entering and leaving glomerular capillaries was estimated from values for protein concentration $(C)$ in femoral arterial $\left(C_{A}\right)$ and in surface efferent arteriolar $\left(C_{E}\right)$ blood plasmas. Colloid osmotic pressure $(\pi)$ was calculated according to the equation derived by Deen et al. (25). Values for $C_{A}$, and thus for $\pi_{A}$, and for femoral arterial plasma are taken as representative for $C$ and $\pi$ in the afferent end of the glomerular capillary network. These estimates of pre- and postglomerular protein concentration permit the calculation of single nephron filtration fraction (SNFF), glomerular capillary $K_{f}$, resistance of single afferent $\left(R_{A}\right)$ and efferent $\left(R_{E}\right)$ arterioles, and initial glomerular capillary plasma flow $\left(\dot{Q}_{A}\right)$ using equations described in detail elsewhere (16).

The volume of fluid collected from individual proximal tubules was estimated from the length of the fluid column in a constant bore capillary tube of known internal diameter. The concentrations of inulin in tubule fluid, plasma, and urine were determined by counting samples in a beta counter (Beckmann Instruments Inc., Palo Alto, 


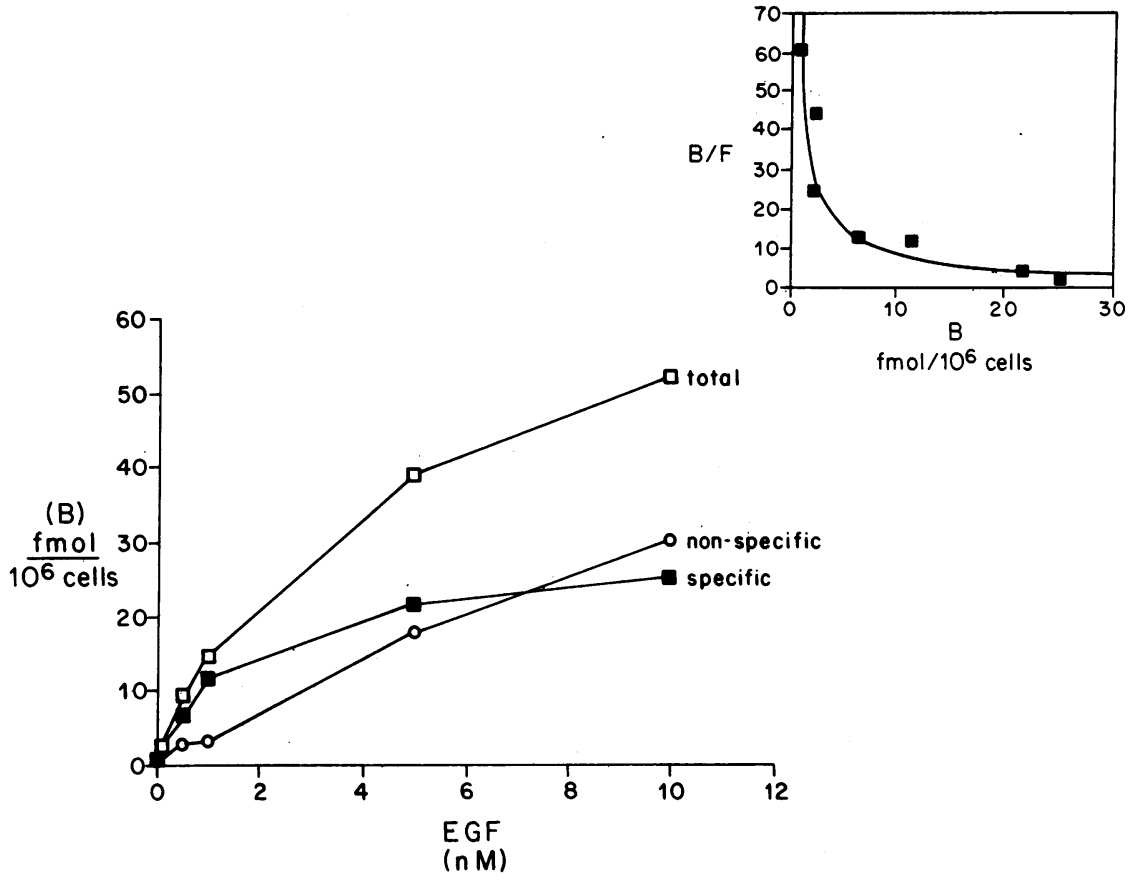

Figure 1. Representative binding at $4^{\circ} \mathrm{C}$ of increasing concentrations of ${ }^{125} \mathrm{I}-\mathrm{EGF}(25-30$ $\mathrm{Ci} / \mathrm{mmol}$ ) to cultured rat glomerular mesangial cells. Inset provides Scatchard transformation of the specific binding.
CA). Protein concentration in efferent arteriolar and femoral arterial blood plasmas were determined using a fluorometric method developed by Viets et al. (26). Urinary concentrations of $\mathrm{Na}^{+}$and $\mathrm{K}^{+}$were measured by flame photometry.

Statistical analysis. Changes from the first to the second period within each group were compared using the Student's $t$ test. A change was considered significant when the $P$ value was $<0.05$. Values are presented as means \pm SEM.

Materials. ${ }^{125} \mathrm{I}-\mathrm{EGF}$ and $\left[{ }^{3} \mathrm{H}\right]$ inulin were obtained from New England Nuclear (Boston, MA), culture grade EGF was obtained from Collaborative Research (Waltham, MA), BCECF was purchased from Molecular Probes, Inc. (Junction City, OR), and nigericin and amiloride were from Sigma Chemical Co. (St. Louis, MO).

\section{Results}

Binding studies to cultured rat mesangial cells. ${ }^{125}$ I-EGF binding to mesangial cells at $23^{\circ} \mathrm{C}$ reached a maximum by $60 \mathrm{~min}$. At $4^{\circ} \mathrm{C}$, maximal binding was not attained until $6 \mathrm{~h}$. Mesangial cells exhibited saturable ${ }^{125}$ I-EGF binding at $4^{\circ} \mathrm{C}$ (Fig. 1) and at $23^{\circ} \mathrm{C}$. (data not shown). There was $73 \pm 8 \%$ specific binding at $4^{\circ} \mathrm{C}(n=4)$ and $83 \pm 4 \%$ specific binding at $23^{\circ} \mathrm{C}(n=9)$. Scatchard transformation of the binding of ${ }^{125} \mathrm{I}-\mathrm{EGF}$ at $4^{\circ} \mathrm{C}$ revealed a nonlinear Scatchard plot (inset, Fig. 1), which was consistent with the presence of two binding sites of differing affinities (27). The high affinity binding site exhibited a $K_{d}$ of $0.1 \mathrm{nM}$ and 1,800 binding sites/cell. The lower affinity binding site had a $K_{\mathrm{d}}$ of $1.7 \mathrm{nM}$ and 8,800 binding sites/cell.

Unlabeled EGF competed for binding with ${ }^{125}$ I-EGF in a concentration-dependent manner (Fig. 2). In addition, transforming growth factor alpha (TGF- $\alpha$ ), a known functional homologue of EGF (28), also competed with ${ }^{125}$ I-EGF for binding to mesangial cells over a concentration range of $10^{-9}-10^{-7}$ $M$ (Fig. 2). In contrast, there was no inhibition of ${ }^{125}$ I-EGF binding by $10^{-6} \mathrm{M}$ arginine vasopressin or angiotensin II, two peptides known to bind specifically to mesangial cells.

$p H_{i}$ studies in cultured rat mesangial cells. The resting $\mathrm{pH}_{\mathrm{i}}$ obtained for cultured mesangial cells in nominally bicarbon- ate-free physiological buffer (see Methods) at $37^{\circ} \mathrm{C}$ was $7.04 \pm 0.04(n=19)$. When cells were placed in an $\mathrm{Na}^{+}$-free solution $(140 \mathrm{mM} \mathrm{NaCl}$ isotonically replaced by tetramethylammonium chloride [TMACl], $\mathrm{pH}$ 7.4), there was a progressive decrease in $\mathrm{pH}_{\mathrm{i}}$. When cells in the $140-\mathrm{mM} \mathrm{NaCl}$ medium were exposed to amiloride $(1 \mathrm{mM}), \mathrm{a} 0.08 \mathrm{pH}$ unit decrease in $\mathrm{pH}_{\mathrm{i}}$ was noted within $5 \mathrm{~min}$.

To determine whether extracellular $\mathrm{Na}^{+}$was necessary for the recovery of $\mathrm{pH}_{\mathrm{i}}$, the mesangial cells were acidified by the $\mathrm{NH}_{4} \mathrm{Cl}$ loading method originally described by Boron and DeWeer (29). After exposure for $7 \mathrm{~min}$ to $50 \mathrm{mM} \mathrm{NH}_{4} \mathrm{Cl}$ in the $\mathrm{NaCl}$ buffer, the medium was then changed to TMACl-containing medium without $\mathrm{NH}_{4} \mathrm{Cl}$, and intracellular acidification ensued. (Fig. 3) No recovery of $\mathrm{pH}_{\mathrm{i}}$ was noted during the succeeding $10 \mathrm{~min}$. When the cells were then returned to an $\mathrm{NaCl}$-containing medium, there was recovery of $\mathrm{pH}_{\mathrm{i}}$, with a rise close to baseline $\mathrm{pH}$.

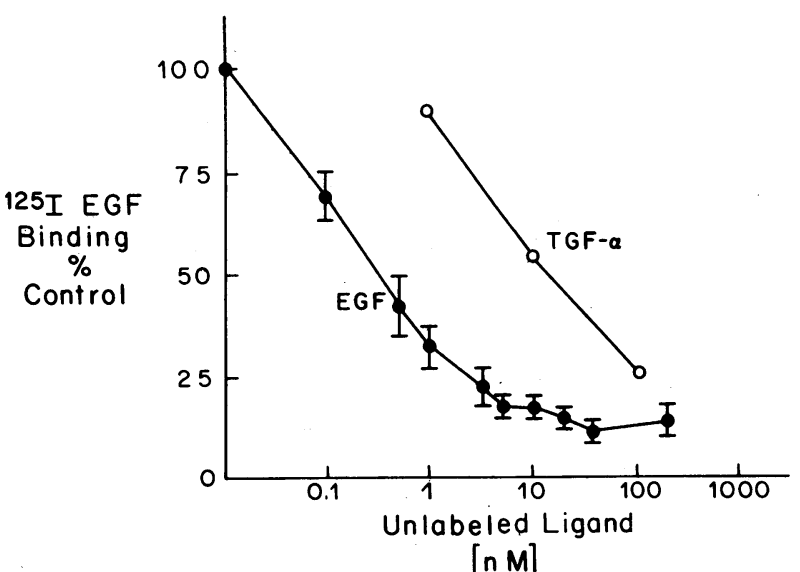

Figure 2. Competitive binding inhibition of ${ }^{125}$ I-EGF $(0.05 \mathrm{nM})$ to mesangial cells by increasing concentrations of unlabeled EGF ( $n$ $=5)$ or TGF- $\alpha(n=2)$. 


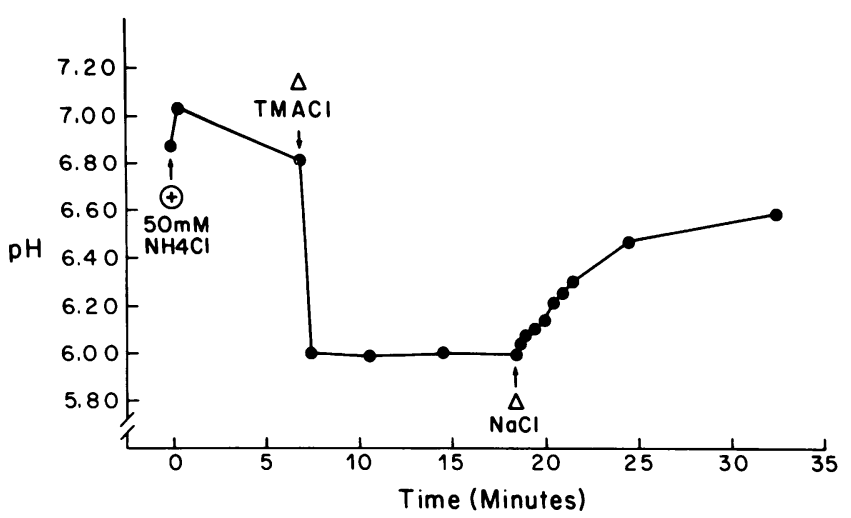

Figure 3. Requirement of extracellular $\mathrm{Na}^{+}$for $\mathrm{pH}_{\mathrm{i}}$ regulation in cultured rat mesangial cells. Mesangial cells were loaded with $5 \mu \mathrm{M}$ BCECF in a nominally bicarbonate-free medium (see text for details) and were acidified by the addition and subsequent removal of 50 $\mathrm{mM} \mathrm{NH}_{4} \mathrm{Cl}$. Tracings here and in Fig. 4 are from representative experiments.

The effects of EGF on the $\mathrm{pH}_{\mathrm{i}}$ of cultured mesangial cells are shown in Fig. $4 \mathrm{~A}$. When EGF was added to cells in the $\mathrm{NaCl}$-containing solution, intracellular alkalinization was noted within 1-5 min. There were no significant differences in the maximal alkalinization induced by the administration of EGF over the concentration range of $1-30 \mathrm{nM}$, with an increase of $\mathrm{pH}_{\mathrm{i}}$ of $0.12 \pm 0.01 \mathrm{pH}$ units $(n=11)$. The alkalinization was largely inhibited by either the preincubation in, or simultaneous addition of, 0.5 or $1.0 \mathrm{mM}$ amiloride (Fig. $4 \mathrm{~B}$ ). Furthermore, no alkalinization response was noted in cells incubated in TMACl-containing medium (Fig. $4 C$ ). When the cells were subsequently returned to $\mathrm{NaCl}$-containing medium, $\mathrm{pH}_{\mathrm{i}}$ recovery was stimulated more than it was in mesangial cells that were not exposed to EGF. In this experiment, there was at least a 2.3-fold increase in the initial rate of $\mathrm{pH}$ recovery compared with similarly treated control cells that had not been exposed to EGF ( 0.34 vs. $0.148 \Delta \mathrm{pH}$ units $/ \mathrm{min}$ ).

Contraction studies. When mesangial cells grown on glass coverslips were exposed to EGF, there were significant changes in cell morphology within $10 \mathrm{~min}$ (Fig. $5, A-C$ ). Noticeable shape alterations in response to EGF were noted in mesangial cells studied on three separate occasions, while no significant change in morphology could be detected in time controls (not shown).

Because shape changes in mesangial cells grown upon glass coverslips may be secondary to either contraction or detachment from the substratum (23), further studies were performed using mesangial cells grown on a silicone rubber substratum. Contraction and relaxation were assessed by changes in the pattern of substratum wrinkling, as described previously by Singhal et al. (23). The administration of EGF induced a time-dependent increase in wrinkling (Fig. 5, D-E), which correlates with cell contraction measurements. Dibutryl cAMP administration led to mesangial cell relaxation (Fig. 5, $G-H$ ) as previously described (23). The subsequent administration of EGF led to a partial recovery of the original pattern of wrinkling (Fig. $5 \mathrm{I}$ ), indicating a recovery of contractile tone.

Micropuncture studies. In group I animals, no significant changes were noted in systemic, whole kidney, or single nephron functional parameters between the first and second periods of vehicle infusion. Relevant values for this group of animals are presented in Table $I$.

Mean values for whole kidney and single nephron functional parameters measured during baseline control conditions and again during EGF administration in group II rats are shown in Table II. In this group of animals, administration of EGF was without significant effect on mean systemic AP $(111 \pm 4-111 \pm 4 \mathrm{mmHg})$ or hematocrit $(46.9 \pm 0.8$ to $46.6 \pm 1.2$ vol\%). Despite the constancy of these systemic parameters, EGF infusion resulted in statistically significant reductions in renal plasma flow (RPF), GFR, and filtration fraction (FF) (from $4.19 \pm 0.33$ to $3.33 \pm 0.26 \mathrm{ml} / \mathrm{min}, P<0.05 ; 1.17 \pm 0.09$ to $0.69 \pm 0.07 \mathrm{ml} / \mathrm{min}, P<0.025$; and $0.28 \pm 0.03$ to $0.22 \pm 0.04, P$ $<0.05$, respectively). In parallel, SNGFR and $\dot{Q}_{A}$ also fell from $51.6 \pm 11.7$ to $28.5 \pm 3.5 \mathrm{nl} / \mathrm{min}(P<0.05)$ and from $142 \pm 9$ to
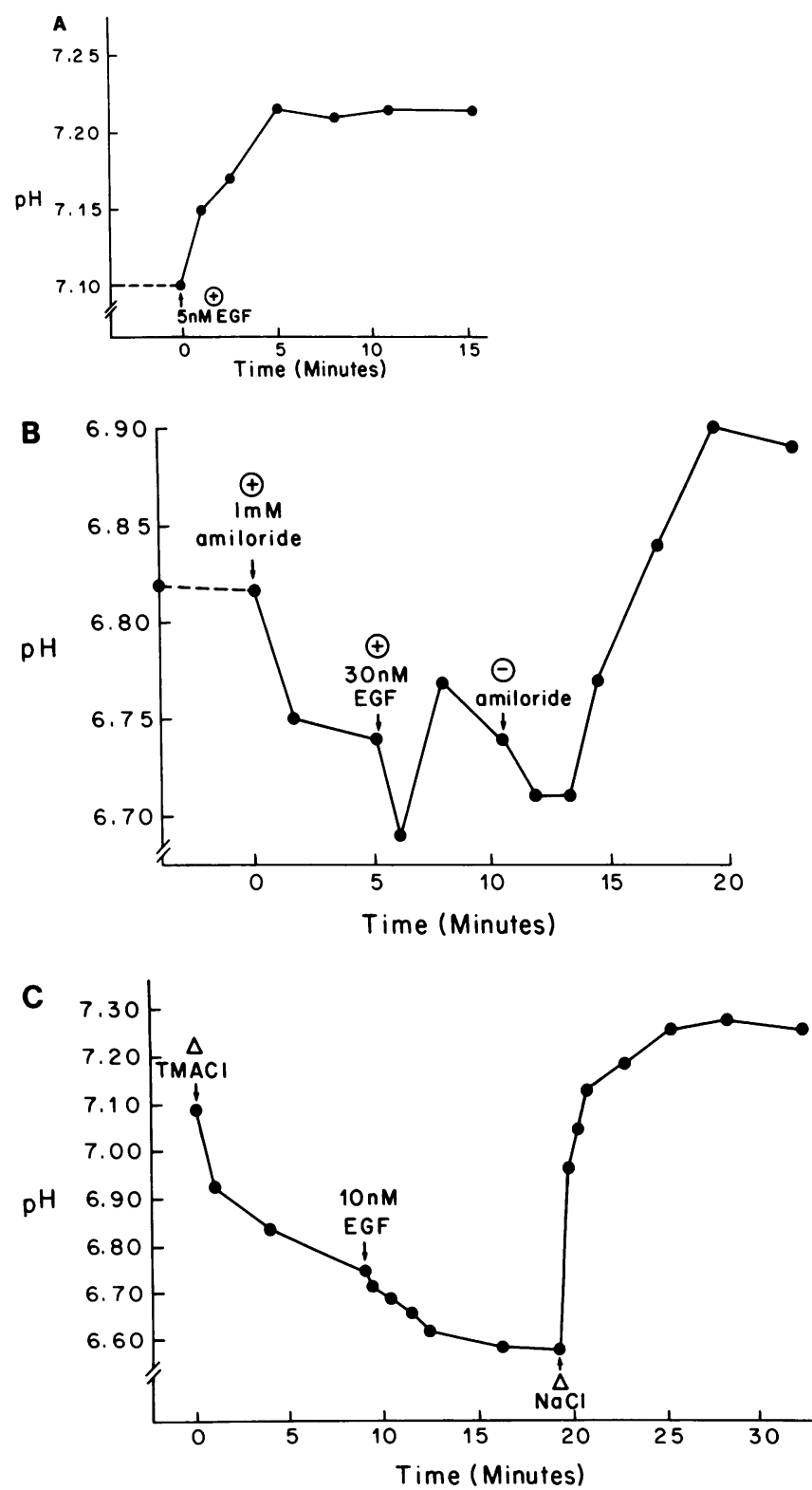

Figure 4. Effect of EGF on $\mathrm{pH}_{\mathrm{i}}$ in rat mesangial cells. $(A) 5 \mathrm{nM}$ EGF, $(B) 30 \mathrm{nM}$ EGF in the presence of $1 \mathrm{mM}$ amiloride, $(C) 10 \mathrm{nM}$ EGF with $\mathrm{TMA}^{+}$substituted for $\mathrm{Na}^{+}$. 

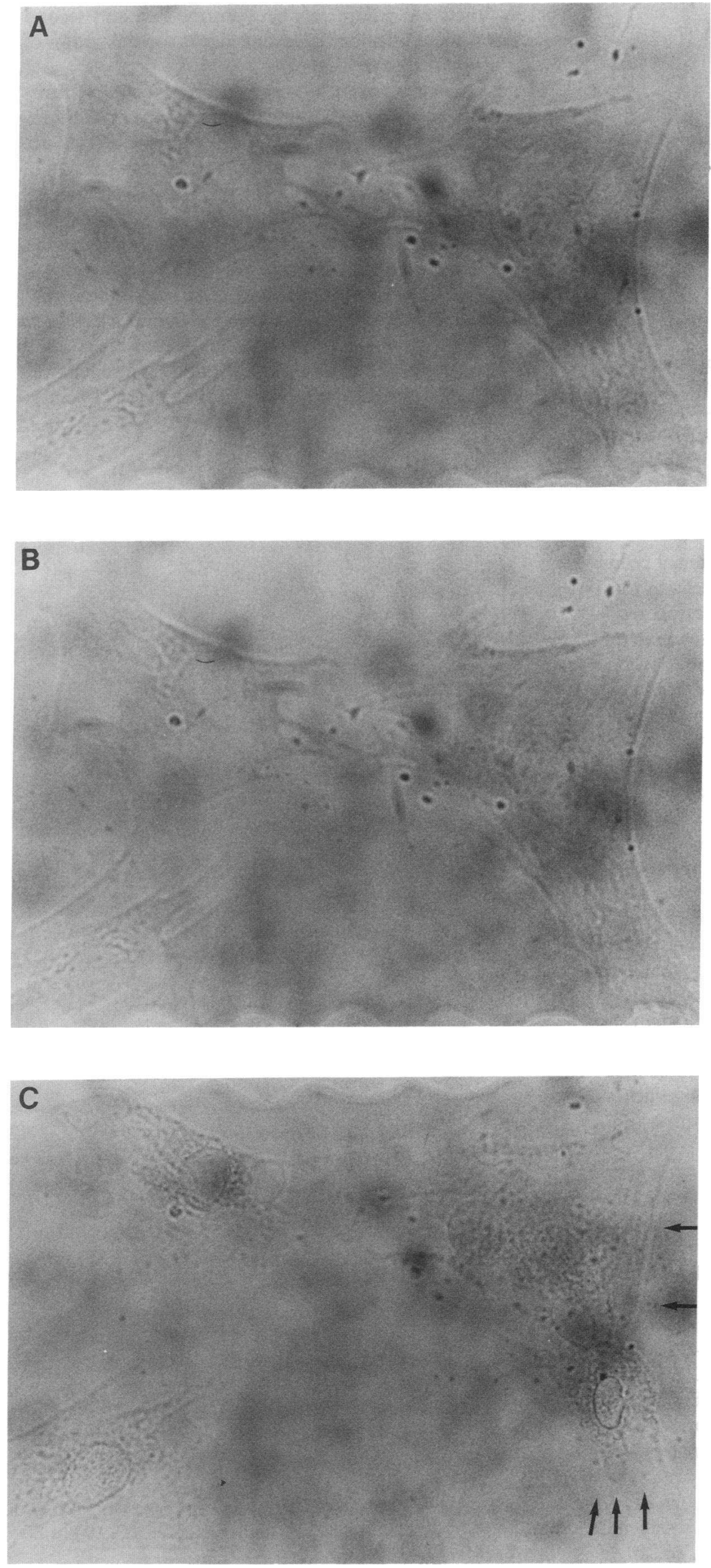

Figure 5. Demonstration of mesangial cell contraction in response to EGF. $(A-C)$ Mesangial cells were grown on glass coverslips and photographed $(A)$ at time $0,(B)$ after $5 \mathrm{~min}$, or $(C)$ after 10-min exposure to 30 nM EGF. Arrows indicate morphologic alterations. $\times 640 .(D-I)$ Mesangial cells were grown on glass coverslips overlain with cross-linked dimethylpolysiloxane. $(D)$ Time $0,(E) 2 \mathrm{~min}$ after addition of EGF (30 nM), $(F) 10 \mathrm{~min}$ after EGF. Note increases in wrinkles after EGF. $(G)$ Time 0, $(H) 5$ min after dibutryl cAMP $\left(10^{-4} \mathrm{M}\right),(I) 10 \mathrm{~min}$ after EGF (30 nM). Note decreases in wrinkles after cAMP and reintroduction after EGF. $\times 100$. 

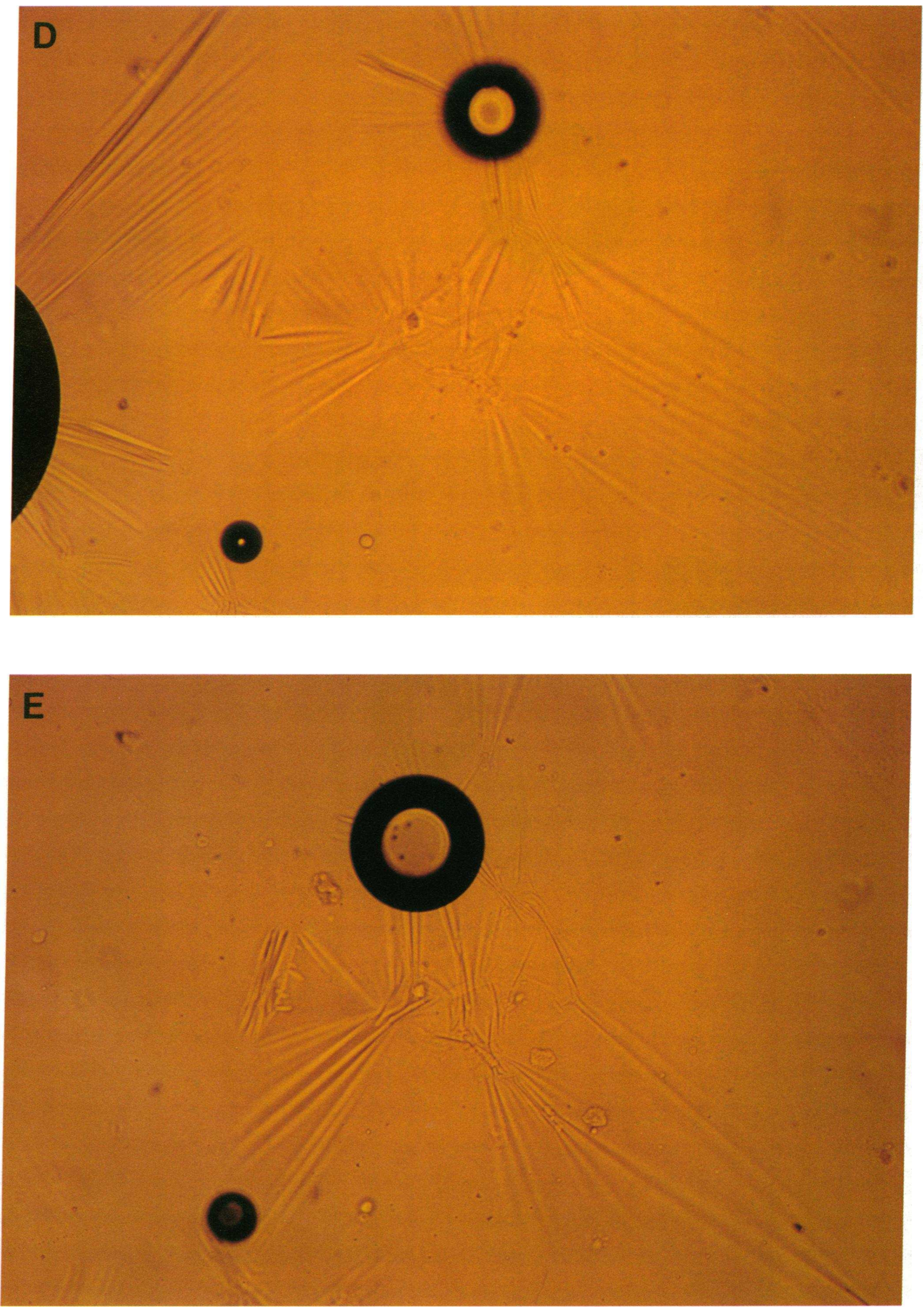

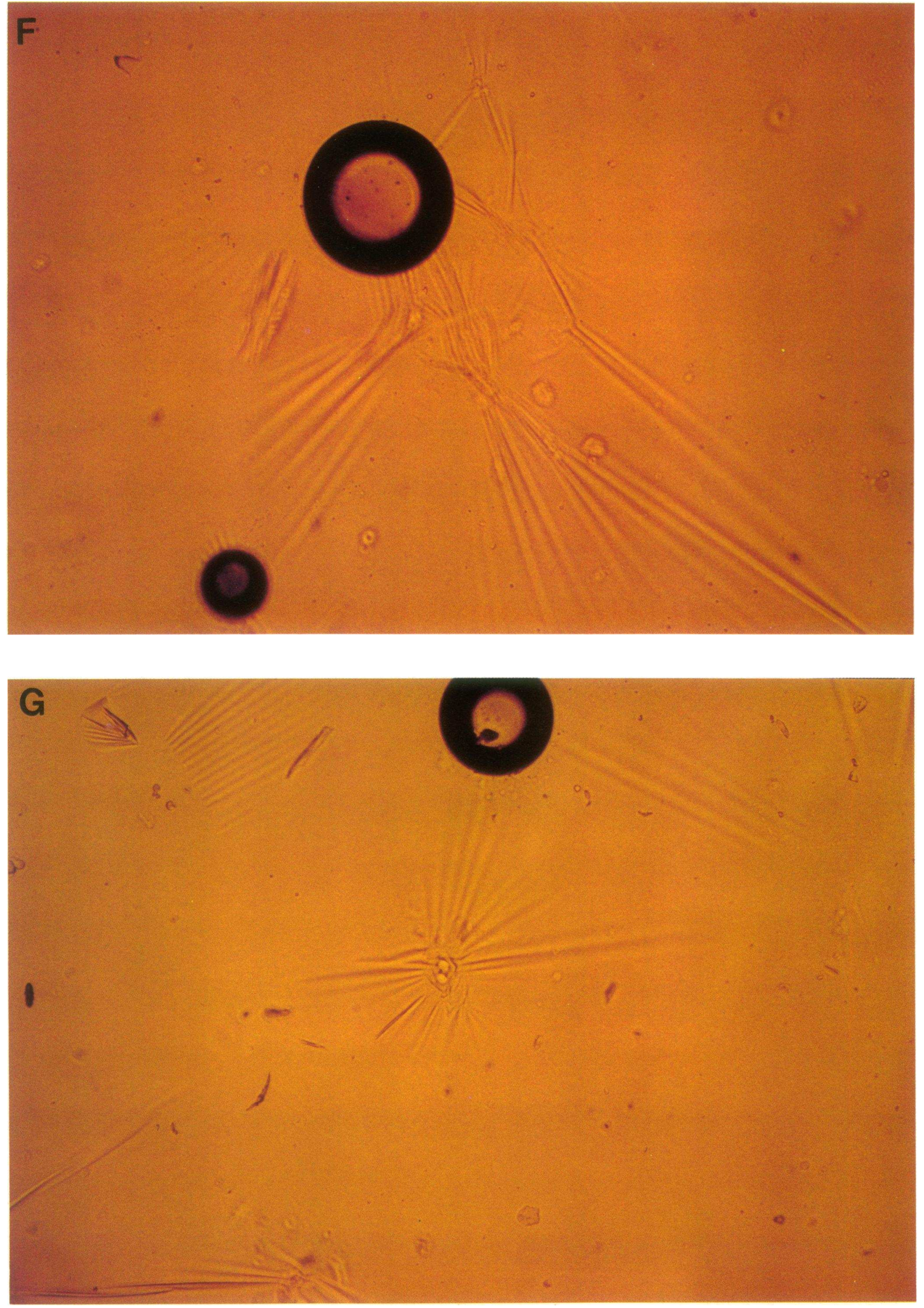

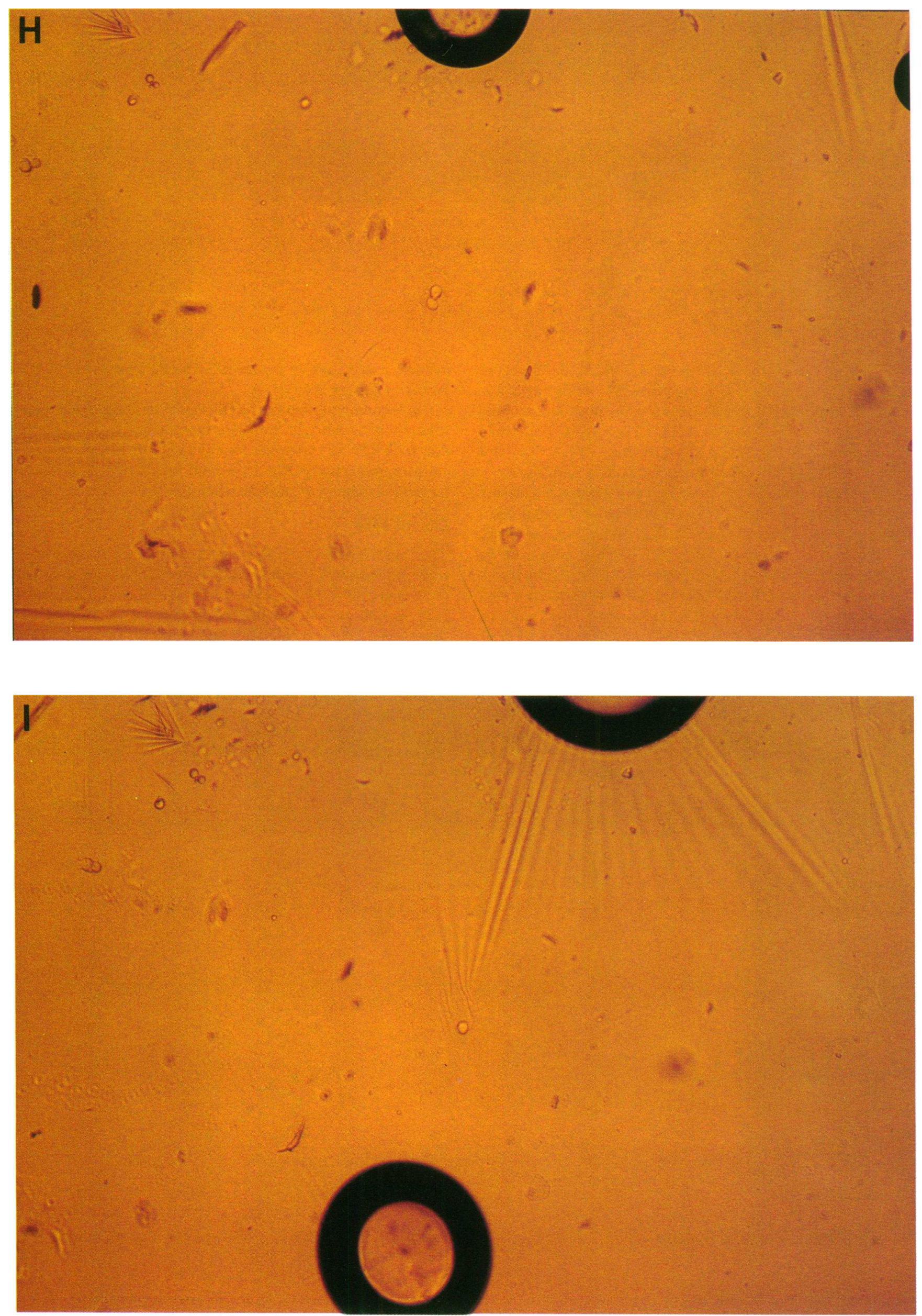
Table I. Summary of Mean ( \pm SEM) Values for Selected Systemic, Whole Kidney, and Single Nephron Functional Parameters During Baseline Control Conditions and Again during Infusion of the EGF Vehicle (0.9\% NaCl) in Group I Animals ( $n=5$ )

\begin{tabular}{|c|c|c|c|c|c|c|c|c|}
\hline & Hematocrit & GFR & RPF & FF & SNGFR & $\dot{Q}_{A}$ & $\Delta \mathbf{P}$ & $K_{\mathrm{f}}$ \\
\hline & volume \% & & & & & & $m m H g$ & $n l / s \cdot m m H g$ \\
\hline \multirow[t]{2}{*}{ Control } & 47.1 & 1.20 & 3.95 & 0.30 & 45.7 & 149 & 37 & 0.093 \\
\hline & 0.1 & 0.07 & 0.40 & 0.02 & 5.3 & 12 & 4 & 0.004 \\
\hline \multirow[t]{2}{*}{ Vehicle } & 45.8 & 1.12 & 3.62 & 0.31 & 43.2 & 139 & 36 & 0.085 \\
\hline & 0.5 & 0.10 & 0.22 & 0.03 & 9.8 & 11 & 3 & 0.003 \\
\hline
\end{tabular}

None of the differences between the two periods were statistically significant.

$98 \pm 8 \mathrm{nl} / \mathrm{min}$, respectively, $(P<0.05)$. Despite the observed reductions in RPF and GFR, urine flow did not decrease during EGF infusion (10.8 $\pm 3.7-10.5 \pm 3.4 \mu \mathrm{l} / \mathrm{min})$. Urinary excretion of $\mathrm{Na}$ and $\mathrm{K}$, however, both fell during EGF administration from $2.1 \pm 0.5$ to $1.3 \pm 0.5 \mu \mathrm{eq} / \mathrm{min}(P<0.025)$ and from $6.7 \pm 1.5$ to $2.9 \pm 1.2 \mu \mathrm{eq} / \mathrm{min}(P<0.005)$, respectively.

Despite the above-noted reductions in glomerular plasma flow and filtration rates, EGF administration was not associated with significant changes in $\mathrm{P}_{\mathrm{GC}}(50 \pm 5-54 \pm 2 \mathrm{mmHg})$, $\mathrm{P}_{\mathrm{T}}(11 \pm 1-10 \pm 1 \mathrm{mmHg}), \Delta \mathrm{P}(38 \pm 5-37 \pm 8 \mathrm{mmHg})$, or $\pi_{\mathrm{E}}$ (35.1 $\pm 4.6-29.4 \pm 3.8 \mathrm{mmHg})$. Calculation of resistances across the afferent $\left(R_{A}\right)$ and efferent $\left(R_{E}\right)$ arterioles, however, revealed significant increases in both values: from $1.97 \pm 0.31$ to $2.65 \pm 0.3610^{10} \mathrm{dyn} \cdot \mathrm{s} \cdot \mathrm{cm}^{-5}(P<0.05)$ and from $1.19 \pm 0.11$ to $2.00 \pm 0.1510^{10} \mathrm{dyn} \cdot \mathrm{s} \cdot \mathrm{cm}^{-5}(P<0.05)$, respectively. Of particular interest, EGF infusion resulted in a highly significant reduction in $K_{\mathrm{f}}$, which fell from $0.100 \pm 0.019$ to $0.031 \pm 0.007$ $\mathrm{nl} /(\mathrm{s} \cdot \mathrm{mmHg}), P<0.025$.

In four animals that were followed for an additional $30 \mathrm{~min}$ after stopping the EGF infusion, there was near-complete recovery of RPF and complete recovery of GFR to 3.47 and 1.37 $\mathrm{ml} / \mathrm{min}$, respectively. The EGF-induced changes in glomerular hemodynamics are summarized in Fig. 6.

\section{Discussion}

The present studies demonstrate the presence of saturable, time-dependent ${ }^{125} \mathrm{I}$-EGF binding to cultured rat glomerular mesangial cells. ${ }^{125}$ I-EGF competed for binding with unlabeled EGF as well as with its functional homologue, TGF- $\alpha$, but there was no competition with angiotensin II or vasopressin, two peptides known to bind to mesangial cells. Scatchard analysis revealed the receptor affinity $\left(K_{d}\right)$ and number of EGF

Table II. Summary of Mean ( \pm SEM) Values for Systemic, Whole Kidney, and Single Nephron Functional Parameters during Baseline Control Conditions and Again during Infusion of EGF in Group II Animals $(n=9)$

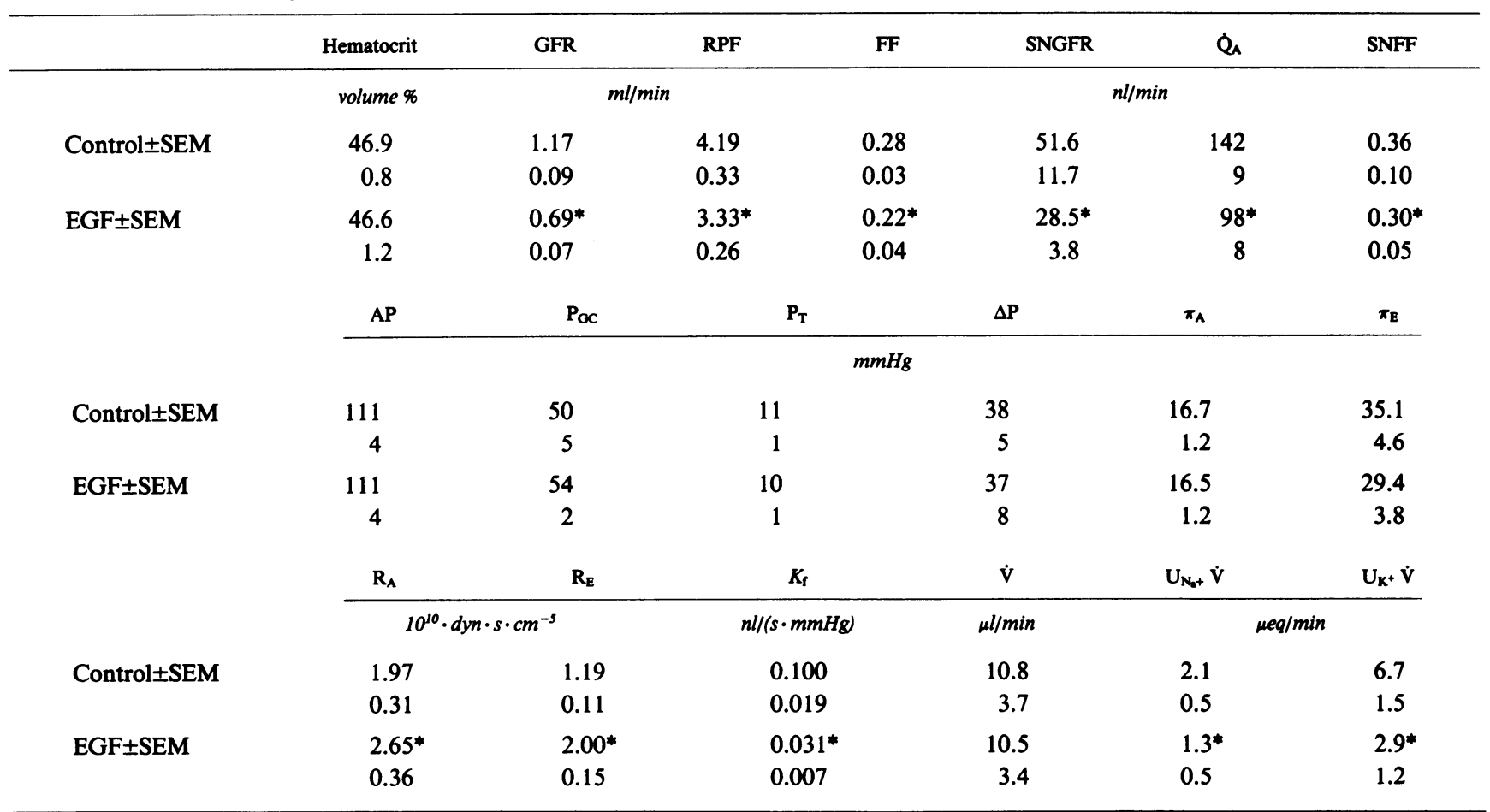

* Statistically significant differences between the two periods. $U_{\mathbf{K}} \dot{V}$, urinary excretion of potassium; $U_{N a} \dot{V}$, urinary excretion of sodium. 


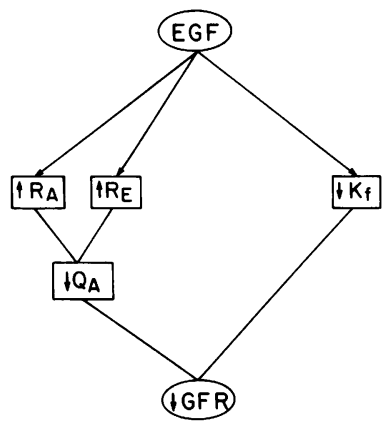

Figure 6. Mechanism of EGF-induced fall in GFR. Through its smooth muscle contractile properties, EGF leads to constriction of pre- and postglomerular arterioles thus producing increases in $\mathbf{R}_{\mathbf{A}}$ and $R_{E}$ and a decrease in $\dot{Q}_{A}$. The latter effect, in combination with a potent reduction of $K_{f}$, leads to the observed fall in GFR.

binding sites per cell obtained in the present studies to be highly consistent with those previously reported for this peptide in other cells. $(27,30)$. Our data are also consistent with the preliminary observation by Tsivitse et al. (31), which suggests the presence of EGF receptors on rat glomerular mesangial cells. The capacity of TGF- $\alpha$ to compete with EGF for binding of the receptor takes on special significance in light of the demonstrated release of TGF- $\alpha$ from activated platelets (32), which are known to be involved in a variety of glomerulopathies (33). Our demonstration of specific receptors for EGF on glomerular mesangial cells suggests the possibility that this potent mitogen may be involved in the proliferative response of these cells observed under a variety of pathologic circumstances (34). In this regard, preliminary studies by Goodyear et al. have revealed an increase in urinary levels of EGF in patients with proliferative glomerulonephritis (35). In addition, Tsivitse et al. have reported that, in a concentration range of EGF similar to that employed in the present studies (1-15 $\mathrm{nM})$, there was a $10-12$-fold increase in $\left[{ }^{3} \mathrm{H}\right]$ thymidine incorporation in cultured human glomerular mesangial cells (31). To examine further the possibility of receptor-mediated, EGF-induced regulation of mesangial cell proliferation, we assessed its capacity to induce intracellular events known to precede mitogenic responses, i.e., intracellular alkalinization.

$\mathrm{pH}_{\mathrm{i}}$ regulation of glomerular mesangial cells in vivo has not yet been studied. The present experiments suggest that, in cultured mesangial cells, in a nominally bicarbonate-free medium, maintenance of $\mathrm{pH}_{\mathrm{i}}$ and recovery from intracellular acidification in these cells are mediated by an $\mathrm{Na}^{+}$-dependent, amiloride-inhibitable mechanism, consistent with $\mathrm{Na}^{+} / \mathrm{H}^{+}$exchange. Similar findings have been reported in preliminary communications by others $(36,37)$. In our studies, incubation of rat glomerular mesangial cells with EGF led to the development of intracellular alkalinization, an effect inhibited by amiloride or by extracellular $\mathrm{Na}^{+}$removal (Fig. 4) EGF-induced activation of $\mathrm{Na}^{+} / \mathrm{H}^{+}$exchange was further suggested by the demonstrated ability of this peptide to stimulate potently the rate of recovery of these cells from experimentally induced intracellular acidification (Figs. 3 and $4 C$ ).

Activation of $\mathrm{Na}^{+} / \mathrm{H}^{+}$exchange is a common feature of growth factor-mediated cellular activation (38), and EGF has been demonstrated previously to activate $\mathrm{Na}^{+} / \mathrm{H}^{+}$exchange in a number of other cell culture systems $(17,39)$. The extension of this observation to the glomerular mesangial cell, however, is of particular interest not only with regard to its implications for proliferative responses, but also in view of the increasingly important role assigned to these cells in the regulation of the functional aspects of glomerular physiology, namely the rate of glomerular ultrafiltration. The demonstration that EGF administration induced the contraction of cultured mesangial cells (Fig. 5), provided further suggestive evidence that this peptide might modulate glomerular hemodynamics in vivo. For this reason, we sought to examine the effect of exogenously administered EGF upon $K_{\mathrm{f}}$, a determinant of SNGFR thought to be dynamically modulated through mesangial cell contraction and relaxation (16).

As shown by the data obtained in group II rats (Table II), intrarenal arterial administration of EGF, in a dose designed to achieve an intrarenal vascular concentration of $3 \mathrm{nM}$, did indeed result in a $70 \%$ reduction in $K_{\mathrm{f}}$. Of interest in this regard is the equipotency of the $K_{\mathrm{f}}$-lowering effect of EGF as compared with that previously reported for angiotensin II (40).

Hormone-induced changes in $K_{\mathrm{f}}$ are thought to be mediated, at least in part, by mesangial cell contraction, thereby altering effective surface area for filtration, although concomitant changes in glomerular-endothelial cell permeability have not been rigorously excluded. $(11,16)$ The observation that agents that lead to decreases in $K_{\mathrm{f}}$ in vivo, also induce the contraction of cultured mesangial cells in vitro (41), is further evidence that these cells have a role in modulating GFR. It is of interest that EGF has previously been reported to induce rapid rounding and cytoskeletal reorganization of human carcinoma A-431 cells (42). More importantly, our own demonstration that cultured glomerular mesangial cells possess specific receptors for EGF and that they contract in response to EGF administration, further supports the notion that the observed in vivo responses represent EGF-induced contraction of these cells.

Little is known about the mechanisms of cellular signal transduction of agents that decrease $K_{\mathrm{f}}$. Recent studies in cultured vascular smooth muscle cells have demonstrated that angiotensin II mediates increased $\mathrm{Na}^{+}$influx and intracellular alkalinization via the activation of $\mathrm{Na}^{+} / \mathrm{H}^{+}$exchange $(18,19)$. A similar activation of $\mathrm{Na}^{+} / \mathrm{H}^{+}$exchange in cultured mesangial cells by vasopressin has been reported in preliminary form (37). That intracellular alkalinization may play a role in the signal transduction of vasoconstrictive agents is further suggested by the observation that amiloride, which blocks $\mathrm{Na}^{+} / \mathrm{H}^{+}$ exchange (43), serves as a vasodilator (44), and that $\mathrm{NH}_{4} \mathrm{Cl}$-induced intracellular alkalinization stimulates (45), and $\mathrm{CO}_{2}$-induced intracellular acidification inhibits (18) the contraction of rat aorta. $\mathrm{NH}_{4} \mathrm{Cl}$-induced intracellular alkalosis also stimulates contraction of cardiac muscle cells (46). The demonstration in the present studies, therefore, of EGF-induced activation of $\mathrm{Na}^{+} / \mathrm{H}^{+}$exchange in rat mesangial cells suggests that such activation may represent an important step in the signal transduction pathway for the contractile, as well as the mitogenic, responses of these cells to EGF.

The demonstration of EGF-induced pre- and postglomerular arteriolar constriction in group II rats is consistent with the studies of Berk et al. and Muramatsu et al., who found that EGF induces contraction of vascular smooth muscle in rat aorta and ileocolic arteries $(9,10)$. In addition, it has been reported that intravenous EGF infusion in awake sheep causes a progressive reduction in renal blood flow and GFR (47). A recent report by Tashjian et al. concluded that chronic EGF administration to mice elevates plasma calcium, which could also theoretically induce renal vascular constriction (48); however, this effect required a number of hours of treatment. In the present studies, the acute intrarenal infusion of EGF did not alter systemic blood pressure or heart rate, making it unlikely that the observed renal response was a nonspecific byproduct of a systemic EGF effect. Finally, the studies of Berk et 
al. and Muramatsu et al. demonstrated a direct constrictive effect of EGF upon isolated artery preparations $(9,10)$. Taken together, these data establish EGF as a potent vasoactive substance with a potential to adversely affect glomerular perfusion and filtration functions when sufficient concentrations of EGF, or its functional analogue, TGF- $\alpha$, are achieved within the glomerular microcirculation.

Oka and Orth determined that the concentration of EGF in human whole blood was $250-300 \mathrm{pg} / \mathrm{ml}(40-50 \mathrm{pM})$; essentially all of the circulating EGF was associated with platelets (15). Although the concentrations of EGF used in the present studies are 50-100 times higher than the concentrations in human blood, release of platelet-associated EGF from alpha secretory granules during platelet aggregation may provide much higher local levels of the peptide at the site of injury. In addition, in human bone marrow, EGF has been immunohistochemically localized to cells resembling monocytes (49). The possibility that the cells resident in the glomerulus under normal conditions or during inflammatory injury themselves produce EGF, has not yet been addressed.

Recently there have been suggestions that the platelets also contain TGF- $\alpha$ (32). In other systems, TGF- $\alpha$ simulates known mitogenic and physiologic effects of EGF (28). The present studies confirm that TGF- $\alpha$ competes for the EGF binding site in cultured mesangial cells. TGF- $\alpha$ also activated $\mathrm{Na}^{+} / \mathrm{H}^{+}$exchange in these cells (data not shown).

It has been shown that removal of the salivary glands and duodenum, the presumed sources of synthesis of circulating EGF in rats, does not affect urinary EGF levels, which suggests that the kidney is a major source of peptide synthesis (50). This is further supported by the studies of Rall et al. (51), which demonstrate the presence of messenger RNA for the EGF precursor pre-proEGF in renal tissue, as well as by other studies that demonstrate high renal EGF levels by immunohistochemical staining (49). Thus, its release from activated platelets, as well as its endogenous renal production, render the present observations on the actions of EGF on glomerular mesangial cells potentially highly relevant with respect to the control of glomerular function under physiologic and/or pathophysiologic conditions.

Examination of urinary flow rates and electrolyte excretion rates during EGF administration (Table II) reveals that although GFR fell by $35-40 \%$, urinary flow rate did not decrease during EGF infusion. This finding, which suggests increased water clearance, is highly consistent with previous observations by Scoggins et al. (47) of increased urine flow rates during lower doses of systemic EGF infusion, and with the demonstration by Breyer and co-workers of a potent inhibitory effect for EGF on the hydroosmotic action of vasopressin in isolated rabbit cortical collecting tubules (52).

A decrease in GFR is usually an early event in the clinical course of a variety of glomerulonephritidies. In acute experimental glomerulonephritis, glomerular micropuncture has revealed that decreases in $K_{\mathrm{f}}$ mediate the fall in GFR (53). Subsequent mesangial cell proliferation is also seen in a variety of glomerulonephritidies (34). Since local glomerular EGF levels may be expected to be elevated during the acute phase of proliferative glomerulonephritis, it is possible that EGF may participate in the mediation of both the acute hemodynamic alterations as well as the subsequent mesangial proliferation. This possibility is highlighted by the recent demonstration of elevated urinary EGF levels in patients with acute proliferative forms of glomerulonephritis (35). That EGF is one of the me- diators of normal or compensatory glomerular growth, is also an intriguing possibility.

In summary, the present studies demonstrate that cultured rat glomerular mesangial cells possess specific receptors for EGF. Exposure of these cells to physiologic concentrations of EGF results in an in vitro functional response characterized as activation of $\mathrm{Na}^{+} / \mathrm{H}^{+}$exchange and induction of intracellular alkalinization. Administration of EGF leads to contraction of cultured mesangial cells. In concert with these in vitro effects, selective intrarenal administration of the peptide in vivo leads to a profound reduction in the glomerular capillary ultrafiltration coefficient which is thought to be mediated, in large part, by changes in glomerular surface area secondary to mesangial cell contraction. The latter response, in combination with significant EGF-induced constriction of both preglomerular and postglomerular arterioles, results in acute and reversible reductions in the rates of glomerular filtration and perfusion. These demonstrated effects of EGF on mesangial cell function and glomerular microcirculatory dynamics raise the intriguing possibility of a potentially significant role for this mitogenic peptide in the functional, as well as the proliferative, responses of the glomerulus during inflammatory injury.

\section{Acknowledgments}

The technical assistance of Chuck Prudhomme, Beverly Hosse, and Alice Gung are gratefully acknowledged.

This work was supported through Veterans Administration Research funds (R. C. Harris) and National Institutes of Health (NIH) grants DK-39261, DK-38667 (K. F. Badr), HL-36526 (R. L. Hoover), and DK-37097-3 (H. R. Jacobson). Dr. Harris is a Research Associate in the Career Development Program of the Veterans Administration. Dr. Hoover is the recipient of an N.I.H. Research Career Development Award (HL-26191).

\section{References}

1. Cohen, S. 1962. Isolation of a mouse submaxillary gland protein accelerating incisor eruption and eyelid opening in the new-born animal. J. Biol. Chem. 237:1555-1562.

2. Carpenter, G., and S. Cohen. 1979. Epidermal growth factor. Annu. Rev. Biochem. 48:193-216.

3. Pratt, R. M., C. S. Kim, and R. I. Grove. 1984. Role of glucocorticoids and EGF in normal and abnormal palatal development. Curr. Top. Dev. Biol. 19:81-101.

4. Deminski, A. B., and L. R. Johnson. 1985. Effect of EGF on development of rat gastric mucosa. Endocrinology. 116:90-95.

5. Rubin, R. A., E. J. O'Keefe, and H. S. Earp. 1982. Alteration of epidermal growth factor-dependent phosphorylation during rat liver regeneration. Proc. Natl. Acad. Sci. USA. 79:776-780.

6. Carpenter, G. 1984. Properties of the receptor for epidermal growth factor. Cell. 37:357-358.

7. Rhodes, J. A., J. P. Tam, U. Finke, M. Saunders, J. Bernanke, W. Silen, and R. A. Murphy. 1986. Transforming growth factor $\alpha$ inhibits secretion of gastric acid. Proc. Natl. Acad. Sci. USA. 83:38443846.

8. Levine, L., and A. Hassid. 1977. Epidermal growth factor stimulates prostaglandin biosynthesis by canine kidney (MDCK) cells. Biochem. Biophys. Res. Commun. 76:1181-1187.

9. Berk, B. C., T. A. Brock, C. Webb, M. B. Taubman, W. J. Atkinson, M. A. Gimbrone, Jr., and R. W. Alexander. 1985. Epidermal growth factor, a vascular smooth muscle mitogen, induces rat aortic contraction. J. Clin. Invest. 75:1083-1086.

10. Muramatsu, I., M. D. Hollenberg, and K. Lederis. 1985. Vascular actions of epidermal growth factor-urogastrone: possible relationship to prostaglandin action. Can. J. Physiol. Pharmacol. 63:994-999.

11. Kreisberg, J. I., M. A. Venkatachalam, R. A. Radnik, and P. Y. Patel. 1985. Role of myosin light-chain phosphorylation and microtu- 
bules in stress fiber morphology in cultured glomerular mesangial cells. Am. J. Physiol. 249(Renal Fluid Electrolyte Physiol. 18):227-235.

12. Sraer, J. D., J. Sraer, R. Ardaillou, and G. Richet. 1980. The glomerulus: site of synthesis and target for hormones and chemical mediators. Adv. Nephrol. 9:293-314.

13. Kreisberg, J. I., and M. J. Karnovsky. 1983. Glomerular cells in culture. Kidney Int. 23:439-447.

14. Bhargava, G., L. Rifas, and M. H. Makmn. 1979. Presence of epidermal growth factor receptors and influence of epidermal growth factor on proliferation and ageing in cultured smooth muscle cells. $J$. Cell. Physiol. 100:365-374.

15. Oka, T., and D. N. Orth. 1983. Human plasma epidermal growth factor $/ \beta$-urogastrone is associated with blood platelets. J. Clin. Invest. 72:249-259.

16. Brenner, B. M., L. D. Dworkin, and I. Ichikawa. 1986. Glomerular ultrafiltration. In The Kidney, 3rd Ed. B. M. Brenner and F. C. Rector, Jr., editors. Saunders, Philadelphia. 124-144.

17. Moolenaar, W. H., Y. Yarden, S. W. deLaat, and J. Schlessinger. 1982. Epidermal growth factor induces electrically silent $\mathrm{Na}^{+}$ influx in human fibroblasts. J. Biol. Chem. 275:8502-8506.

18. Berk, B. C., M. S. Aronow, T. A. Brock, E. Cragoe, Jr., M. A. Gimbrone, Jr., and R. W. Alexander. 1987. Angiotensin II-stimulated $\mathrm{Na}^{+} / \mathrm{H}^{+}$exchange in cultured vascular smooth muscle cells. Evidence for protein kinase C-dependent and -independent pathways. J. Biol. Chem. 262:5057-5064.

19. Hatori, N., B. P. Fine, A. Nakamura, E. Crogoe, Jr., and A. Aviv. 1987. Angiotensin II effect on cytosolic $\mathrm{pH}$ in cultured rat vascular smooth muscle cells. J. Biol. Chem. 262:5073-5078.

20. Harper, P. A., J. M. Robinson, R. L. Hoover, T. C. Wright, and M. J. Karnovsky. 1984. Improved methods for culturing rat glomerular cells. Kidney Int. 26:875-880.

21. Thomas, J. A., R. N. Buchsbaum, A. Zimniak, and E. Racker. 1979. Intracellular pH measurements in Ehrlich ascites cells utilizing spectroscopic probes generated in situ. Biochemistry 18:2210-2215.

22. Harris, A. K., P. Wild, and D. Stopak. 1980. Silicone rubber substrata: a new wrinkle in the study of cell locomotion. Science (Wash. DC). 208:177-179.

23. Singhal, P. C., L. A. Scharschmidt, N. Gibbons, and R. M. Hays. 1986. Contraction and relaxation of cultured mesangial cells on a silicone rubber surface. Kidney Int. 30:862-873.

24. Ichikawa, I., D. A. Maddox, M. G. Cogan, and B. M. Brenner. 1979. Dynamics of glomerular ultrafiltration in euvolemic MunichWistar rats. Renal Physiol. 1:121-131.

25. Deen, W. M., J. L. Troy, C. R. Robertson, and B. M. Brenner. 1973. Dynamics of glomerular ultrafiltration in the rat. IV. Determination of the ultrafiltration coefficient. J. Clin. Invest. 52:1500-1508.

26. Viets, J. W., W. M. Deen, J. L. Troy, and B. M. Brenner. 1978. Determination of serum protein concentration in nanoliter blood samples using fluorescamine or $o$-phthaldehyde. Anal. Biochem. 88:513521.

27. Schlessinger, J. 1986. Allosteric regulation of the epidermal growth factor receptor kinase. J. Cell Biol. 103:2067-2072.

28. Derynck, R. 1986. Transforming growth factor- $\alpha$ : structure and biological activities. J. Cell. Biochem. 32:293-304.

29. Boron, W. F., and P. DeWeer. 1976. Intracellular pH transients in squid giant axons caused by $\mathrm{CO}_{2}, \mathrm{NH}_{3}$, and metabolic inhibitors. $J$. Gen. Physiol. 67:91-112.

30. King, A. C., and P. Cuatrecasas. 1982. Resolution of high and low affinity epidermal growth factor receptors: inhibition of high affinity component by low temperature, cycloheximide and phorbol esters. J. Biol. Chem. 257:3053-3060.

31. Tsivitse, P., H. E. Abboud, C. Saunders, and T. C. Knauss. 1987. Effect of epidermal growth factor (EGF) on cultured mesangial cells. Kidney Int. 31:184A. (Abstr.)

32. Assoian, R. K., G. R. Grotendorst, D. M. Miller, and M. B. Sporn. 1984. Cellular transformation by coordinated action of three peptide growth factors from human platelets. Nature (Lond.). 309:804-806.
33. Cameron, J. S. 1977. Platelets and glomerulonephritis. Nephron. 18:253-258.

34. Wilson, C. B., and F. J. Dixon. Renal response to immunological injury. 1986. In The Kidney, 3rd Ed. B. M. Brenner and F. C. Rector, Jr., editors. Saunders, Philadelphia. 800-890.

35. Goodyer, P. R., Z. Kachra, C. Goodyer, and B. Kaplan. 1987. Potential role for EGF in proliferative glomerulonephritis. Kidney Int. 31:167A. (Abstr.)

36. Boyarsky, G., M. Ganz, R. B. Sterzel, and W. F. Boron. 1987. Optical study of pH regulation in single cultured glomerular mesangial cells. Kidney Int. 31:161A. (Abstr.)

37. Cantiello, H. F., J. Angel, D. A. Ausiello, and J. V. Bonventre. 1987. Ca modulates a $\mathrm{Na} / \mathrm{H}$ exchanger in mesangial cells. Kidney Int. 31:162A. (Abstr.)

38. Grinstein, S., and A. Rothstein. 1986. Mechanisms of regulation of the $\mathrm{Na}^{+} / \mathrm{H}^{+}$exchanger. J. Membr. Biol. 90:1-12.

39. Macara, I. G. 1986. Activation of ${ }^{45} \mathrm{Ca}^{++}$influx and ${ }^{22} \mathrm{Na}^{+} / \mathrm{H}^{+}$ exchange by epidermal growth factor and vanadate in A431 cells is independent of phosphatidylinositol turnover and is inhibited by phorbol ester and diacylglycerol. J. Biol. Chem. 261:9321-9327.

40. Ichikawa, I., J. F. Miele, and B. M. Brenner. 1979. Reversal of renal cortical actions of angiotensin II by verapamil and manganese. Kidney Int. 16:137-147.

41. Ausiello, D. A., J. J. Kriesberg, C. Roy, and M. J. Karnovsky. 1980. Contraction of cultured rat glomerular cells after stimulation with angiotensin II and arginine vasopressin. J. Clin. Invest. 65:754760.

42. Chinkers, M., J. A. McKanna, and S. Cohen. 1979. Rapid induction of morphological changes in human carcinoma cells A-431 by epidermal growth factor. J. Cell. Biol. 83:260-265.

43. Kinsella, J. L., and P. S. Aronson. 1981. Amiloride inhibition of the $\mathrm{Na}^{+}-\mathrm{H}^{+}$exchanger in renal microvillus membrane vesicles. Am. J. Physiol. 241:F374-F379.

44. Haddy, F. J., M. P. Pamnani, B. T. Swindall, J. Johnson, and E. J. Cragoe. 1985. Sodium channel blockers are vasodilators as well as natriuretic and diuretic agents. Hypertension 7(Suppl. I):I121-I1 26.

45. Shepherd, J. T. 1983. Circulation to skeletal muscle. Hand. Physiol.

46. Vaughan-Jones, R. D., D. A. Eisner, and W. J. Lederer. 1987. Effects of changes of intracellular $\mathrm{pH}$ on contraction in sheep cardiac Purkinje fibers. J. Gen. Physiol. 89:1015-1032.

47. Scoggins, B. A., A. Butkus, J. P. Coghlan, D. Fei, J. G. McDougall, H. D. Niall, J. R. Walsh, and X. Wang. 1984. In vivo cardiovascular, renal and endocrine effects of epidermal growth factor in sheep. Endocrinology. 573-576.

48. Tashjian, A. H., Jr., E. F. Voelkel, W. Lloyd, R. Derynick, M. E. Winkler, and L. Levine. 1986. Actions of growth factors on plasma calcium. Epidermal growth factor and human transforming growth factor-alpha cause elevation of plasma calcium in mice. $J$. Clin. Invest. 78:1405-1409.

49. Kasselberg, A. G., D. N. Orth, M. E. Gray, and M. T. Stahlman. 1985. Immunocytochemical localization of human epidermal growth factor/urogastrone in several human tissues. J. Histochem. Cytochem. 33:315-322.

50. Olsen, S., P. S. Paulsen, P. Kirkegaard, and E. Nexo. 1984. Renal origin of urinary epithelial growth factor in the rat. Regul. Pept. 10:37-47.

51. Rall, L. B., J. Scott, G. I. Bell, R. S. Crawford, J. D. Penschow, H. D. Niall, and J. P. Caughlan. 1985. Mouse prepro-epidermal growth factor synthesis by the kidney and other tissues. Nature (Lond.). 313:228-231.

52. Breyer, M., H. R. Jacobson, and J. Breyer. 1988. Epidermal growth factor inhibits vasopressin-stimulated hydraulic conductivity in isolated perfused rabbit cortical collecting tubule. J. Clin. Invest. In press.

53. Blantz, R. C., and C. B. Wilson. 1976. Acute effects of antiglomerular basement membrane antibody on the process of glomerular filtration in the rat. J. Clin. Invest. 58:899-911. 